\title{
Determinants of Labour Force Participation in the Philippines
}

\author{
Regina M. Lizares ${ }^{\mathrm{a}}$ \\ University of the Philippines \\ Carlos C. Bautistab \\ University of the Philippines
}

\begin{abstract}
This empirical study identifies the main determinants of labour force participation in the Philippines. The results demonstrate that the decision to participate in the labour force is influenced by location, sex, age, marital status and educational level. The rural man, single individual, who is older and possesses a higher educational level is more likely to participate in the labour force. Furthermore, difference in labour force participation rates between the rural and urban areas is due primarily to differences in behavioural responses to variables explaining participation (the coefficient effect) and not so much to differences in sub-population characteristics.
\end{abstract}

Keywords: Decomposition analysis, labour force participation, labour force survey, logit analysis, Philippines

JEL classification: J21, J82

\section{Introduction}

Labour is the most abundant factor of production of any nation. Consequently, a nation's long-run well-being depends heavily on the willingness of its people to work (Ehrenberg \& Smith, 2018).

The labour force participation rate (LFPR) is the fraction of the working age population (15 years old (y.o.) and over) currently employed or actively looking for employment; it is a behavioural variable that reflects choices that working-age individuals make about how to spend their time (Daly \& Regev, 2007). It provides an indication of the size of the supply of labour available to engage in the production of goods and services (International Labour Organization (ILO), n.d.).

The LFPR is important for many reasons. One, it plays a central role in studying the factors that determine the size and composition of a nation's human resources and in projecting its future supply of labour. Two, it is an input in policy formulation, especially those which have to do with employment. Among others, it helps to determine training needs, as well as to calculate the expected working lives of the population and the rates

a Cesar E.A. Virata of School of Business, University of the Philippines, Diliman, Quezon City 1101, Philippines. Email: rmlizares@up.edu.ph (Corresponding author)

b Cesar E.A. Virata of School of Business, University of the Philippines, Diliman, Quezon City 1101, Philippines. Email: bautista@up.edu.ph

Article Info: Received 18 January 2020; Revised 18 September 2020; Accepted 30 September 2020 https://doi.org/10.22452/MJES.vol57no2.7 
of accession to, and retirement from, economic activity; these are crucial information for the financial planning of social security systems (ILO, n.d.; Juhn \& Potter, 2006). Three, it is used for understanding the labour market behaviour of different categories of the population. The level and pattern of LFPR depends on employment opportunities and the demand for income, which may differ from one category of persons to another. LFPR among the young (15-24 y.o.) reflects the availability of educational opportunities, while LFPR among the old (55-64 y.o.) gives an indication of the attitude towards retirement and the existence of social safety nets for the retired. LFPR is generally lower for women than for men in each age category. Women in the first half of their prime working age (25-39 y.o.) tend to leave the labour force to give birth to and raise children, returning - but at a lower rate - to economically active lives when the children are older (ILO, n.d.).

Labour supply is possibly the area in labour economics most researched in the last 30 years. Studies on labour supply in the Philippines cover a variety of topic, such as migration, unemployment and regional markets. A few studies focus on labour force participation (LFP) - such as the effect on LFP of fertility (Encarnacion, 1974), of children (Orbeta, 2005), as well as studies focused on women LFP (e.g., Bayudan-Dacuycuy, 2019; Tiefenthaler, 1994). Yet, this is possibly the first Philippine study exploring the determinants of LFP, as well as the differences in LFPR in urban versus rural areas, the knowledge of which can serve as a baseline to measure the effect of certain policy and programme changes on LFP.

This empirical study identifies the main determinants of LFP in the Philippines using data from the first quarter Labour Force Survey (LFS) of 2011 and 2016 (Philippine Statistics Authority (PSA), 2011, 2016). This study also identifies the main determinants in the changes in LFPR via a decomposition analysis.

The decision to participate in the labour force is influenced by location, sex, age, marital status and educational level. The rural man, single individual, who is older and possesses a higher educational level is more likely to participate in the labour force. Further decomposing the difference in LFPR between the rural and urban areas shows that this variance is driven more by differences in behaviour as shown by the coefficient effect rather than by population characteristics.

The outcome of this study, a better understanding of the determinants of LFP, informs public policy particularly on the effect of education on LFP and increasing women LFP. First, given the significant positive impact of education on LFP, policies and programmes that encourage attendance and completion of higher educational levels should be supported by various means. Second, given the economic growth impact of increased women LFP, policies and programmes that increase the incentives and decrease the deterrents for their entry and re-entry into the labour force should be pursued.

Given the baseline nature of this study, it can be extended by taking a more dynamic approach to the study of LFP; exploring trends in different categories of the population (e.g., the declining trend in men and youth LFPR, flat trend in women LFPR); and investigating trends in various variables (e.g., decline in LFPR for individuals in certain educational levels). 


\section{Review of Literature}

Labour supply and its behaviour are often studied using the neoclassical model of labour-leisure choice. This model isolates the factors that determine whether an individual chooses paid work over leisure, and how many hours s/he chooses to work. The decision to participate in the labour force involves a comparison of the market wage with the reservation wage - the wage that makes an individual indifferent between working and not working. This model has been expanded beyond the labourleisure choice to sharpen the analysis, taking into account: (1) household production and intra-familial decisions to work; and (2) intra-temporal characteristics, such as lifecycle and business cycles. (See Borjas (2013), Cahuc, Carcillo and Zylberberg (2014), and Ehrenberg and Smith (2018) for a detailed discussion on labour supply economics.)

Labour supply is possibly the area of labour economics which has the greatest number of empirical studies carried out in the last 30 years, shedding light on the determinants of labour supply (Cahuc et al., 2014; Ehrenberg \& Smith, 2018). This increase has been driven by the advancement in econometric methods, and by the need to evaluate public policies (Cahuc et al., 2014), such as the effect on work incentives of changes in the wage rate, income tax reform, and welfare programmes, as well as the effect on labour force participation of the retirement age and pension benefits. (See Cahuc et al., 2014, pp. 71-76.)

Two early significant studies on the determinants of LFP emerged from the United States in the 1960s and the 1970s. First, Bowen and Finnegan's (1969) book The Economics of Labour Force Participation can be considered the first comprehensive explanation of the factors which determine LFP in the United States. They extended the econometric study of labour supply to cover sub-groups of the population which had until then marginal to no attention - youth, older people, men and unmarried women. Their regression results show a positive relationship between LFP and earning power, and a negative relationship with non-labour income. This corroborates the generally accepted finding that the net result of changes in labour market unemployment is changes in the opposite direction of LFP (Fleisher, 1971). Second, Cullison's (1979) empirical paper tests a reduced form model of labour supply, and aims to determine the extent to which the acceleration in LFP is due to economic rather than sociological forces. His empirical results firmly show that workers in various categories of the population respond differently to various economic incentives and disincentives; also, that the unusually rapid labour force growth in the United States is related to both economic as well as sociological forces.

Studies on the determinants of LFP have since expanded geographically outside of the United States, expanding to other developed economies (e.g., Grigoli, Koczan, \& Topalova, 2018), as well as developing economies (e.g., Contreras, De Mello, \& Puentes, 2011). Studies have also concentrated their focus on a category of the population, be it by sex (e.g., Jaumotte, 2003), age (e.g., Clark \& Anker, 1993), or rural-urban split (e.g., Scott, Smith, \& Rungeling, 1977), as well as intersection of categories (e.g., sex and marital status of Fernández, Fogli, \& Olivetti, 2004). Studies by population categories aim to capture the different labour force behaviour of each group, especially on the sex split; the different roles men and women typically play in performing household work 
and child-bearing and rearing activities clearly affect the labour supply (Ehrenberg \& Smith, 2018).

There are several studies tackling the Philippines labour supply, covering various topics, such as, but not limited to, migration (e.g. Rodriguez \& Tiongson, 2001), unemployment (e.g. Brooks, 2002), and regional labour markets (e.g., Montalvo, 2006). There are also some studies specific to LFP, such as the effect on LFP of fertility (Encarnacion, 1974), of children (Orbeta, 2005), as well as studies focused on women LFP (e.g., Bayudan-Dacuycuy, 2019; Tiefenthaler, 1994). However, there are no prior studies, as far as the authors are aware, that focuses on the determinants of overall LFP.

\section{Trends in the Philippines LFPR}

The Philippine labour force has been growing by $2.4 \%$ per annum (p.a.) since 2000 , but LFPR has been on a downtrend since the early 2000s, in line with the global trend (see Figure 1).

Similar to the findings in the United States of Aaronson, Hu, Seifoddini and Sullivan (2014), as well as Daly and Regev (2007), these declines in the Philippine are due to: (1) decline in the men LFPR; (2) flattening out of the once-rising women LFPR; and (3) decline in the youth (15-24 y.o.) (see Figure 2). Further studies exploring the root causes and impact of these phenomenon can be conducted.

The decline in men LFRP has been studied in the United States by Tüzemen, (2018), but not in the Philippines. He ascertained that the decline stemmed from: (1) younger men of prime working age, ages 25-34 y.o.; and (2) men with middle levels of educational attainment - a high school degree, some college, or an associate's degree;

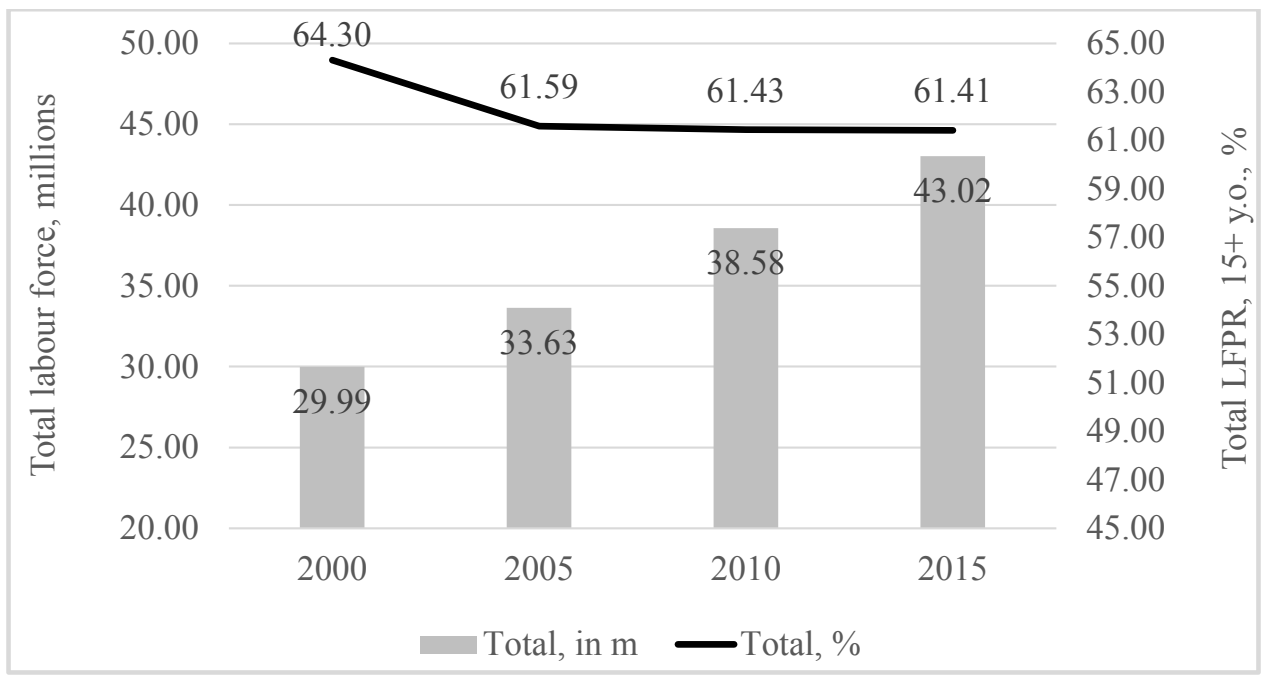

Figure 1. Total labour force and total labour force participation rate Source: World Bank, 2020.

https://data.worldbank.org/indicator/SL.TLF.TOTL.IN?locations=PH (Total labour force) https://data.worldbank.org/indicator/SL.TLF.CACT.NE.ZS?locations=PH\&view=chart (Total LFPR) 


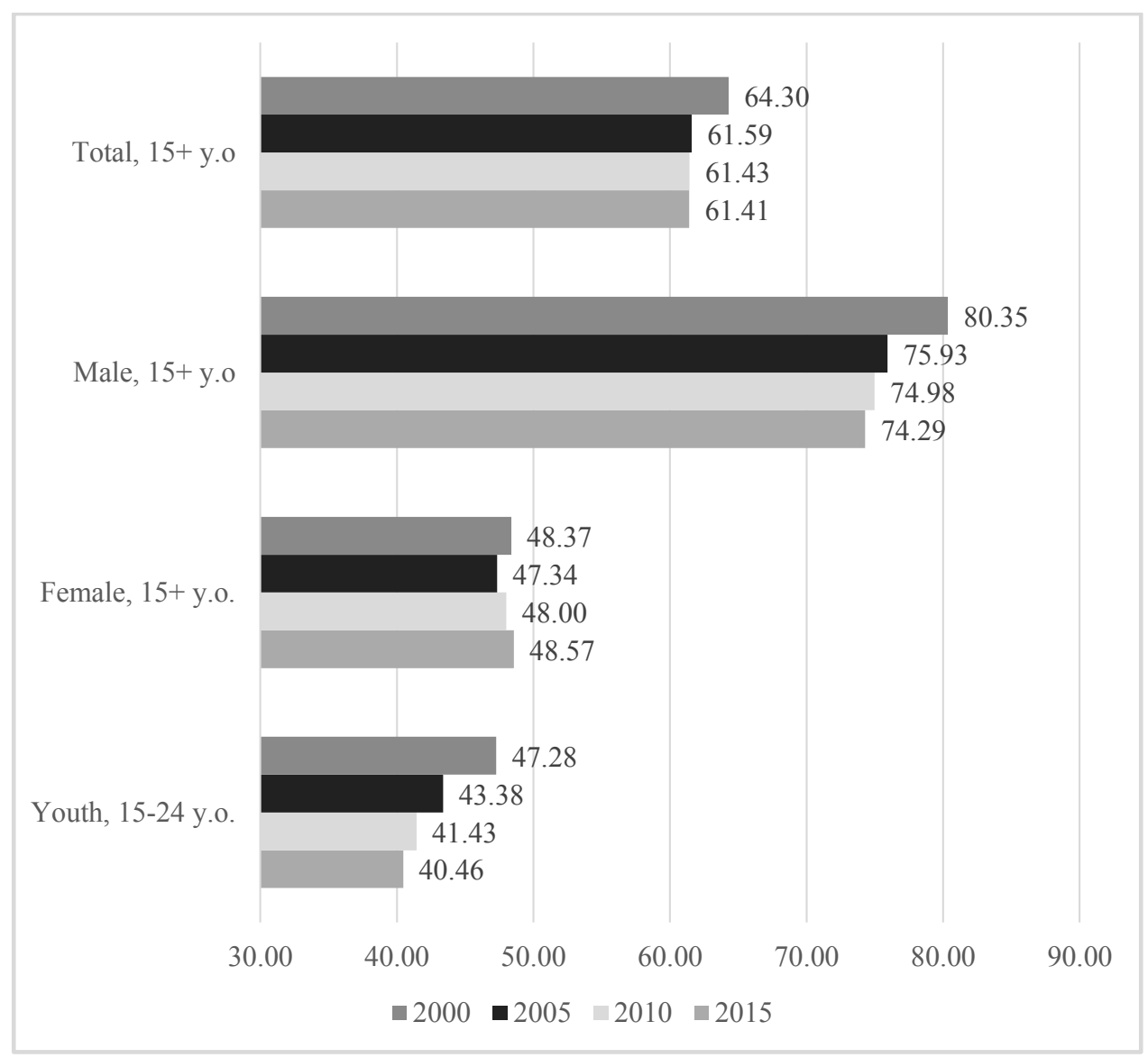

Figure 2. Labour force participation rate by total, sex and youth categories Source: World Bank, 2020.

https://data.worldbank.org/indicator/SL.TLF.CACT.NE.ZS?locations=PH\&view=chart (Total) https://data.worldbank.org/indicator/SL.TLF.CACT.MA.NE.ZS?locations=PH\&view=chart (Male) https://data.worldbank.org/indicator/SL.TLF.CACT.FE.NE.ZS?locations=PH\&view=chart (Female) https://data.worldbank.org/indicator/SL.TLF.ACTI.1524.NE.ZS?locations=PH (Youth)

and he further argued that a decline in the demand for middle-skill workers accounts for most of the decline in LFP among prime-age men.

The women LFPR has remained relatively flat for the period 1990 to 2015 . This is in contrast to the women LFPR of neighbouring countries like Indonesia, Malaysia and Singapore; all these countries have improved from their LFPR levels of between $45 \%$ and $48 \%$ in the 1990 s, with Singapore registering the biggest increase at 13 percentage points (Bayudan-Dacuycuy, 2019).

The decline in youth LFPR may be due to their choice of schooling over employment - with possibly the returns to schooling rising and opportunities for those without advanced education declining. 


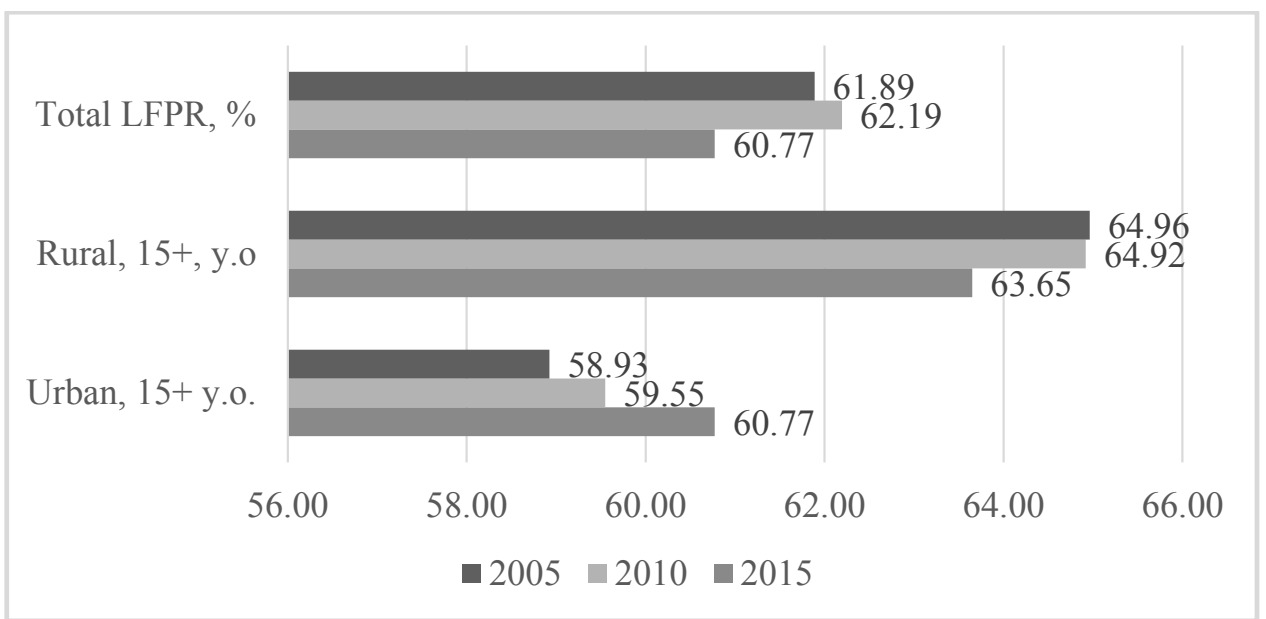

Figure 3. Labour force participation rate by total and urban-rural categories, ILO estimates Source: ILO, 2019.

Note: According to the ILO (2018, p. 73) report, the Philippines has three population size thresholds in its definition of urban areas: (1) cities and municipalities with at least 1,000 inhabitants per square kilometre; (2) administrative centres, barrios with 2,000 inhabitants or more: and (3) barrios with 1,000 inhabitants or more which are contiguous to the administrative centre, in all cities and municipalities with at least 500 inhabitants per square kilometre.

LFPR in the rural and urban areas, like total LFPR, have been relatively stable for the period 2005 to 2015. A slight decline in LFPR is seen in the rural area, compensated by an increase in the urban area for the period 2015 versus 2010.

\section{Data, Variables and Descriptive Results}

This study uses data from the first quarter LFS of 2011 and 2016 (PSA, 2011, 2016). The LFS is a nationwide quarterly survey conducted by the PSA during the months of January, April, July, and October. This study limits the labour force to 15-64 y.o. as 65 y.o. is the legal retirement age in the Philippines. There are over 120,000 observations in each year.

The choice of first quarter 2016 was limited by data availability, as this was the latest and most complete data PSA could share with the researchers at the start of this study. The researchers then chose data five years back at a time to provide ample time for changes in LFP. The 2006 results, however, are not reported given there were no changes when compared with the 2011 results. ${ }^{1}$

Table 1 summarises the study's variables, descriptions and measurements, while Table 2 shows the correlation matrix.

Age and Marital status display the highest significant (positive) correlation coefficients at 0.5881 in 2016 and 0.6108 in 2011. This indicates that Age and changes in Marital status move together. All other variables, some of which show significant relationships, have correlations coefficients of less than 0.1400 in both years.

1 The results are available upon request. 
Table 3 describes the 2011 and 2016 data in detail. Of the total individuals sampled, approximately two-thirds participated in the labour force and one-third did not.

Table 1. Variables, descriptions and measurements

\begin{tabular}{|c|c|c|}
\hline Variables & Descriptions & Measurements \\
\hline \multicolumn{3}{|l|}{$\begin{array}{l}\text { Dependent } \\
\text { variable }\end{array}$} \\
\hline LFP & $\begin{array}{l}\text { - Decision to participate or } \\
\text { not in the labour force }\end{array}$ & $\begin{array}{l}\text { - Binary variable that captures if a working-age } \\
\text { age individual is: } 0 \text { - Not in the labour force; } \\
\text { or } 1-\text { In the labour force, either by working } \\
\text { or looking for work }\end{array}$ \\
\hline \multicolumn{3}{|l|}{$\begin{array}{l}\text { Independent } \\
\text { variable }\end{array}$} \\
\hline Location & $\begin{array}{l}\text { Reflects the array of } \\
\text { employment opportunities } \\
\text { available to the individual }\end{array}$ & $\begin{array}{l}\text { - Binary variable that captures if the individual } \\
\text { resides in: } 0 \text { - Urban; or } 1 \text { - Rural area }\end{array}$ \\
\hline Sex & - Demographic characteristic & $\begin{array}{l}\text { - Binary variable that captures if the individual } \\
\text { is: } 0 \text { - Male; or } 1 \text { - Female }\end{array}$ \\
\hline Age & - Demographic characteristic & $\begin{array}{l}\text { - Continuous variable, that captures the } \\
\text { individual's age as of last birthday in years }\end{array}$ \\
\hline Age squared & $\begin{array}{l}\text { - Captures the non-linear } \\
\text { effect of age (Contreras et } \\
\text { al., 2011) }\end{array}$ & $\begin{array}{l}\text { - Continuous variable that captures any non- } \\
\text { linear effects of the variable age in years }\end{array}$ \\
\hline Marital status & - Demographic characteristic & $\begin{array}{l}\text { - Categorical variable that captures the } \\
\text { individual's marital status: } 1 \text { - Single; } \\
2 \text { - Married; } 3 \text { - Widowed; or } 4 \text { - Divorced/ } \\
\text { Separated/Annulled }\end{array}$ \\
\hline $\begin{array}{l}\text { Educational } \\
\text { level }\end{array}$ & - Stock of human capital & $\begin{array}{l}\text { - Categorical variable that captures the } \\
\text { individual's highest educational attainment: } \\
1 \text { - No grade completed; } 2 \text { - Elementary } \\
\text { undergraduate; } 3 \text { - Elementary graduate; } \\
4 \text { - High school undergraduate; } 5 \text { - High } \\
\text { school graduate; } 6 \text { - College undergraduate; } \\
7 \text { - College graduate }\end{array}$ \\
\hline \multicolumn{3}{|l|}{$\begin{array}{l}\text { Control } \\
\text { variable }\end{array}$} \\
\hline Region & $\begin{array}{l}\text { Reflects the array of } \\
\text { employment opportunities } \\
\text { available to the individual }\end{array}$ & $\begin{array}{l}\text { - Categorical variable that captures which of } \\
\text { the } 17 \text { political regions the individual is part } \\
\text { of. All regions are a mix of urban and rural } \\
\text { characteristics, except for National Capital } \\
\text { Region (NCR) which is all urban }\end{array}$ \\
\hline
\end{tabular}


Table 2. Correlation table

\begin{tabular}{|c|c|c|c|c|c|}
\hline Variables & Region & Age & Age squared & $\begin{array}{l}\text { Marital } \\
\text { status }\end{array}$ & $\begin{array}{c}\text { Educational } \\
\text { level }\end{array}$ \\
\hline \multicolumn{6}{|l|}{2011} \\
\hline Region & 1.0000 & & & & \\
\hline Age & -0.0011 & 1.0000 & & & \\
\hline Age squared & -0.0029 & $0.9855^{*}$ & 1.0000 & & \\
\hline Marital status & $0.0168^{*}$ & $0.6108^{*}$ & $0.5646^{*}$ & 1.0000 & \\
\hline Educational level & $0.0243^{*}$ & $-0.1145^{*}$ & $-0.1393^{*}$ & $-0.0789 *$ & 1.0000 \\
\hline \multicolumn{6}{|l|}{2016} \\
\hline Region & 1.0000 & & & & \\
\hline Age & -0.0053 & 1.0000 & & & \\
\hline Age squared & $-0.0066^{*}$ & $0.9859 *$ & 1.0000 & & \\
\hline Marital status & $0.0166^{*}$ & $0.5881^{*}$ & $0.5451^{*}$ & 1.0000 & \\
\hline Educational level & $0.0276^{*}$ & $-0.1194^{*}$ & $-0.1390 *$ & $-0.0855^{*}$ & 1.0000 \\
\hline
\end{tabular}

Note: * Correlation coefficients significant at the $5 \%$ level.

Table 3. Description of the labour data used in the study (percentage)

\begin{tabular}{|c|c|c|c|c|c|c|}
\hline & \multicolumn{3}{|c|}{2011} & \multicolumn{3}{|c|}{2016} \\
\hline & $\begin{array}{c}\% \text { of } \\
\text { total } \\
\text { sample }\end{array}$ & $\begin{array}{l}\text { Not in } \\
\text { labour } \\
\text { force }\end{array}$ & $\begin{array}{c}\text { In } \\
\text { labour } \\
\text { force }\end{array}$ & $\begin{array}{c}\% \text { of } \\
\text { total } \\
\text { sample }\end{array}$ & $\begin{array}{l}\text { Not in } \\
\text { labour } \\
\text { force }\end{array}$ & $\begin{array}{c}\text { In } \\
\text { labour } \\
\text { force }\end{array}$ \\
\hline Total & & 34.18 & 65.82 & & 34.74 & 65.26 \\
\hline \multicolumn{7}{|l|}{ Region } \\
\hline I - Ilocos Region & 5.40 & 35.23 & 64.77 & 5.43 & 34.57 & 65.43 \\
\hline II - Cagayan Valley & 4.68 & 31.42 & 68.58 & 5.01 & 30.67 & 69.33 \\
\hline III - Central Luzon & 8.02 & 37.71 & 62.29 & 8.04 & 35.22 & 64.78 \\
\hline IVA - CALABARZON & 9.65 & 34.03 & 65.97 & 10.12 & 33.56 & 66.44 \\
\hline IVB - MIMAROPA & 3.91 & 28.47 & 71.53 & 2.64 & 31.84 & 68.16 \\
\hline V-Bicol & 5.39 & 34.60 & 65.40 & 5.64 & 34.60 & 65.40 \\
\hline VI - Western Visayas & 6.67 & 32.69 & 67.31 & 6.54 & 32.85 & 67.15 \\
\hline VII - Central Visayas & 6.54 & 33.64 & 66.36 & 6.15 & 33.10 & 66.90 \\
\hline VIII - Eastern Visayas & 5.12 & 33.37 & 66.63 & 5.26 & 36.17 & 63.83 \\
\hline IX - Zamboanga Peninsula & 4.13 & 33.87 & 66.13 & 4.04 & 34.14 & 65.86 \\
\hline X - Northern Mindanao & 4.44 & 30.03 & 69.97 & 4.53 & 32.88 & 67.12 \\
\hline XI - Davao & 5.61 & 32.54 & 67.46 & 5.91 & 34.04 & 65.96 \\
\hline XII - SOCCSKSARGEN & 5.11 & 34.03 & 65.97 & 5.00 & 34.41 & 65.59 \\
\hline XIII - CARAGA & 4.18 & 32.57 & 67.43 & 4.12 & 33.75 & 66.25 \\
\hline National Capital Region & 11.96 & 35.57 & 64.43 & 11.22 & 36.21 & 63.79 \\
\hline
\end{tabular}


Table 3. Continued

\begin{tabular}{|c|c|c|c|c|c|c|}
\hline & \multicolumn{3}{|c|}{2011} & \multicolumn{3}{|c|}{2016} \\
\hline & $\begin{array}{c}\% \text { of } \\
\text { total } \\
\text { sample }\end{array}$ & $\begin{array}{l}\text { Not in } \\
\text { labour } \\
\text { force }\end{array}$ & $\begin{array}{c}\text { In } \\
\text { labour } \\
\text { force }\end{array}$ & $\begin{array}{c}\% \text { of } \\
\text { total } \\
\text { sample }\end{array}$ & $\begin{array}{l}\text { Not in } \\
\text { labour } \\
\text { force }\end{array}$ & $\begin{array}{c}\text { In } \\
\text { labour } \\
\text { force }\end{array}$ \\
\hline $\begin{array}{l}\text { Cordillera Administration } \\
\text { Region }\end{array}$ & 4.44 & 31.42 & 68.58 & 4.13 & 29.71 & 70.29 \\
\hline $\begin{array}{l}\text { Autonomous Region in } \\
\text { Muslim Mindanao }\end{array}$ & 4.77 & 44.63 & 55.37 & 6.23 & 47.22 & 52.78 \\
\hline Total & 100.00 & & & 100.00 & & \\
\hline \multicolumn{7}{|l|}{ Location } \\
\hline Urban & 47.36 & 35.97 & 64.03 & 45.72 & 35.95 & 64.05 \\
\hline Rural & 52.64 & 32.57 & 67.43 & 54.28 & 33.73 & 66.27 \\
\hline Total & 100.00 & & & 100.00 & & \\
\hline \multicolumn{7}{|l|}{ Sex } \\
\hline Male & 50.67 & 19.88 & 80.12 & 50.94 & 21.84 & 78.16 \\
\hline Female & 49.33 & 48.87 & 51.13 & 49.06 & 48.13 & 51.87 \\
\hline Total & 100.00 & & & 100.00 & & \\
\hline \multicolumn{7}{|l|}{ Age } \\
\hline Youth, 15-24 y.o. & 32.31 & 54.97 & 45.03 & 31.79 & 58.91 & 41.09 \\
\hline Prime age $1,25-39$ y.o. & 29.76 & 24.67 & 75.33 & 28.88 & 24.30 & 75.70 \\
\hline Prime age $2,40-54$ y.o. & 26.81 & 20.88 & 79.12 & 26.65 & 19.43 & 80.57 \\
\hline Older, 55-64 y.o. & 11.12 & 31.27 & 68.73 & 12.69 & 30.12 & 69.88 \\
\hline Total & 100.00 & & & 100.00 & & \\
\hline \multicolumn{7}{|l|}{ Marital status } \\
\hline Single & 38.30 & 45.38 & 54.62 & 38.67 & 48.48 & 51.52 \\
\hline Married & 56.75 & 27.10 & 72.90 & 55.79 & 26.06 & 73.94 \\
\hline Widowed & 3.35 & 31.14 & 68.86 & 3.35 & 29.93 & 70.07 \\
\hline $\begin{array}{l}\text { Divorced/Separated/ } \\
\text { Annulled }\end{array}$ & 1.59 & 23.44 & 76.56 & 2.18 & 20.76 & 79.24 \\
\hline Total & 100.00 & & & 100.00 & & \\
\hline \multicolumn{7}{|l|}{ Educational level } \\
\hline No grade completed & 1.84 & 38.24 & 61.76 & 1.78 & 39.20 & 60.80 \\
\hline Elementary undergraduate & 12.65 & 22.30 & 77.70 & 12.46 & 23.49 & 76.51 \\
\hline Elementary graduate & 13.38 & 26.63 & 73.37 & 12.21 & 26.88 & 73.12 \\
\hline High school undergraduate & 18.29 & 50.45 & 49.55 & 17.64 & 51.64 & 48.36 \\
\hline High school graduate & 25.40 & 31.72 & 68.28 & 30.36 & 31.65 & 68.35 \\
\hline College undergraduate & 16.37 & 45.90 & 54.10 & 12.76 & 53.25 & 46.75 \\
\hline College graduate & 12.07 & 18.96 & 81.04 & 12.79 & 18.18 & 81.82 \\
\hline Total & 100.00 & & & 100.00 & & \\
\hline
\end{tabular}


Regionally, the National Capital Region, Region IVA - CALABARZON and Region III - Central Luzon are the three regions with the larger representation in the sample, with each comprising between $8 \%$ to $12 \%$ of the total sample. This is around double the representation of the other regions, which are each at between $4 \%$ to $5 \%$ of the sample. The same range of approximately two-thirds LFPR is generally seen across all the regions except for the Autonomous Region in Muslim Mindanao (ARMM), which has a LFPR of a little over one-half. This is possibly due to the persistent unrest and insurgence in the region, which may have led to under-investment and uncertainty.

Individuals in rural areas have slightly greater (3\% to $5 \%$ more) representation in the sample than those in urban areas. Also, there is approximately $3 \%$ more LFP in the rural versus the urban areas.

Men and women are equally represented in the sample. However, they show very different LFP with men LFPR at close to $80 \%$ and women LFPR at approximately $51 \%$. This is above the global average women LFPR of 48\% (World Bank, 2019).

The 15-64 y.o. age range of the sample disaggregates into four narrower age range, in line with the ILO (2017). Combined prime category (25-54 y.o.) comprises the largest category at $55 \%$ of the sample, followed by the youth category (15-24 y.o.) at $32 \%$, and the older category (55-64 y.o.) at $12 \%$. LFPR is lowest in the youth category, peaks in the prime category, and tapers off in the older category albeit still above the level of that in the youth category.

Over half of the sample surveyed are married, and they show LFPR greater than $70 \%$ - higher than the overall average of approximately two-thirds. Meanwhile, singles are the next largest represented group at $38 \%$ of the sample surveyed, and they show LFPR of just above $50 \%$.

Of the seven categories in educational level, high school graduates are the most represented at $25 \%$ to $30 \%$; each of the other categories are significantly lower in representation. LFPR is highest with college graduates at $81 \%$, followed by elementary undergraduates and elementary graduates at over $70 \%$ each; all three categories have LFPR greater than the overall average LFPR of approximately two-thirds. It seems reasonable to expect that each step up in the education ladder should see an increase in LFPR. However, LFPR dips between elementary graduate to high school undergraduate and between high school graduate to college undergraduate. Exploring the reasons for these dips in LFPR is a possible area of future research.

\section{Logit Analysis and LFP}

The unit of observation in this study is the individual who either participates or does not participate in the labour market. This study uses logit regression to examine the factors that influence the individual's participation decision. For a binary response variable $y$, and a vector of explanatory variables $\boldsymbol{x}$, the regression model that arises from a logistic distribution is of the form:

$$
\operatorname{Pr}(y=1 \mid \boldsymbol{x})=F(\boldsymbol{x} \boldsymbol{\beta})=\frac{\exp (\boldsymbol{x} \boldsymbol{\beta})}{1+\exp (\boldsymbol{x} \boldsymbol{\beta})}
$$

where $\boldsymbol{\beta}$ are the logit regression coefficients to be estimated. Note that these coefficients do not directly reflect the effects of the variables on the dependent variable 
and are not easy to interpret as they are on a logit scale. One should instead calculate the marginal effects of $x$ on $y$ as:

$$
\frac{\partial \operatorname{Pr}(y=1 \mid \boldsymbol{x})}{\partial \boldsymbol{x}}=\frac{d F(\boldsymbol{x} \boldsymbol{\beta})}{d(\boldsymbol{x} \boldsymbol{\beta})} \boldsymbol{\beta}=\frac{\exp (\boldsymbol{x} \boldsymbol{\beta})}{[1+\exp (\boldsymbol{x} \boldsymbol{\beta})]^{2}} \boldsymbol{\beta}
$$

Table 4 shows the coefficient estimates and the marginal effects of the logit regression. Educational level, amongst all the independent variables, has the largest, consistent (positive) and significant effect on LFP. Increases in educational attainment drives the likelihood of participation in the labour force by approximately 14 percentage points with the completion of elementary undergraduate, 11 percentage points for elementary graduate, three percentage points for high school undergraduate (only in 2016), as much as 10 percentage points for high school graduate, and 19 to 21 percentage points for college graduate. This greater LFP may be due to the more educated individuals increased propensity to seek employment, or the greater opportunity cost of staying out of the labour market. Either way, educational attainment and LFP is important in understanding the returns of education (Bowen \& Finegan, 1966).

However, college undergraduate level shows a negative significant effect on LFP, decreasing the likelihood of participation in the labour force by around three percentage points. This decline may be due to two possible reasons. One, it may be due to personal, family reasons, such as illness, disability or caring for a family member. Or two, it may be due to 'discouraged worker effect', where an individual stops searching for a likely job after a long period of unsuccessful job search, which may be due to market conditions, or the individual's inadequate experience, qualifications, or education (ILO, 2017). Understanding the cause of this decline in the likelihood of participation in the labour force is a possible area of future research.

Age has the next largest, consistent (positive) significant effect on LFP, increasing the likelihood of participation in the labour force by almost six percentage points. However, age has a non-linear decelerating effect on LFP as seen by the negative significant coefficient of Age squared, possibly attributable to higher likelihood of illness or retirement as an individual gets older. As an individual ages, s/he likely attains a higher educational level, accumulates work experience, earns higher wages, and experiences increasing life responsibilities; all of these makes an individual more employable and more motivated to participate in the labour force. Furthermore, viewing the labour-leisure choice over the entire working life of an individual can possibly result in the individual choosing labour currently in exchange for leisure later, especially as the individual approaches retirement (Borjas, 2013, p. 64).

Marital status have different effects on LFP. Overall, transitioning to married status has a negative significant effect on LFP, decreasing the likelihood of participation in the labour force by $3.5 \%$ (2016) to as much as $6.4 \%$ (2011). This is likely heavily skewed towards women. From being a single decision-maker, who is assumed to maximise his or her own utility, the individual now transitions to a joint decision-making process: (1) to allocate the time of each individual; and (2) to agree on who does what in the household (Ehrenberg \& Smith, 2018, p. 276). The decisions on who does paid market work and household work are heavily influenced by customs and gender-role expectations. 
Table 4. Regression results

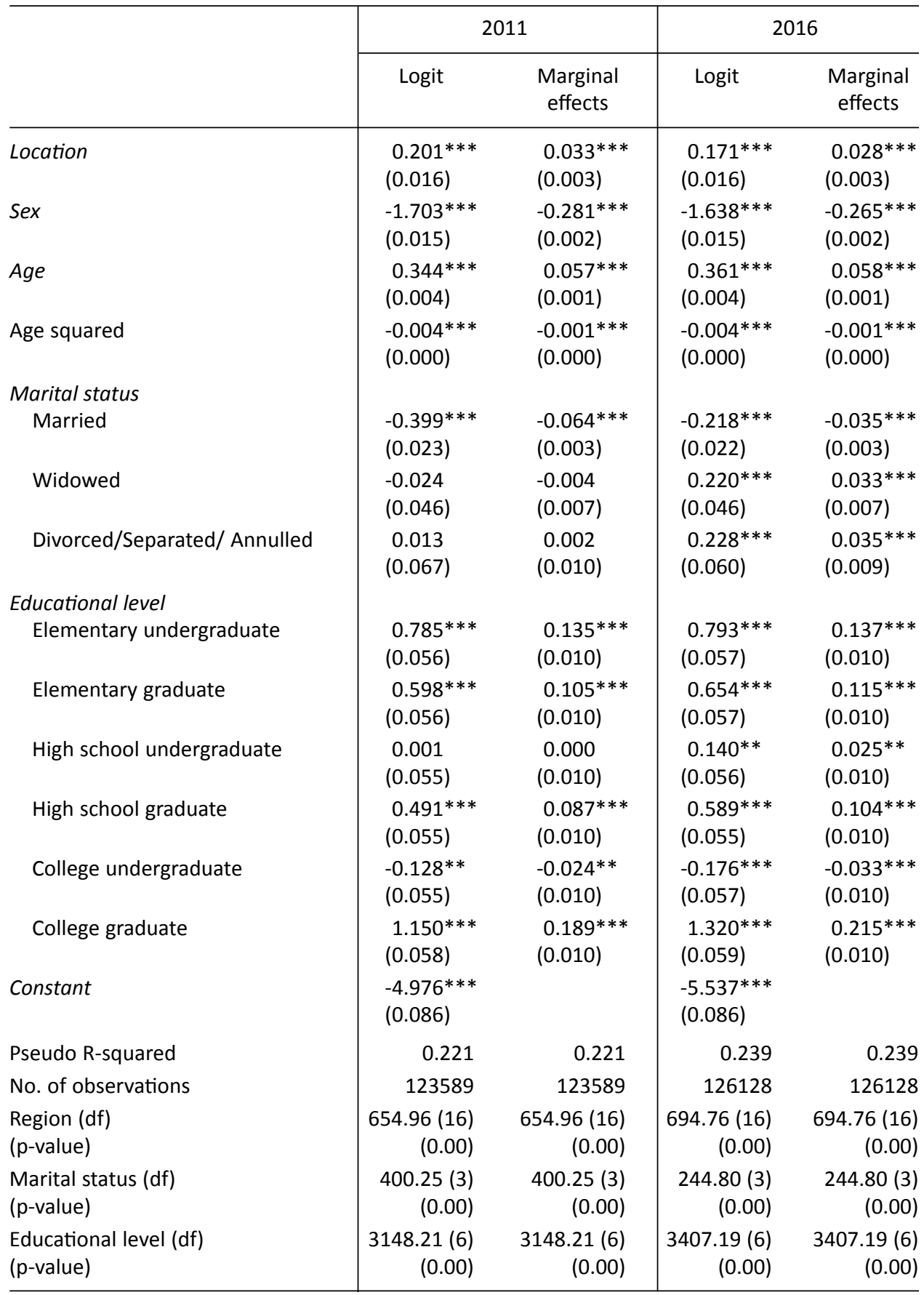

Note: Standard errors in parentheses; $d f=$ degrees of freedom; ${ }^{*} \mathrm{p}<0.10,{ }^{* *} \mathrm{p}<0.05,{ }^{* * *} \mathrm{p}<0.01$. 
Meanwhile, overall transitioning back to singlehood either by choice (divorced, separated or annulled) or not (widowed) has a positive significant effect on LFP, increasing the likelihood of participation in the labour force by approximately three percentage points, but only in 2016. The individual transitions back to a single decisionmaker, and possibly back to a single-household income.

Location and Sex also have significant effects on LFP, albeit in opposite directions. An individual from a rural area has a higher likelihood of participation in the labour force by over three percentage points than an individual from an urban area. Also, a woman has a lower likelihood of participation on the labour force by almost three percentage point. These results on Location and Sex align with the LFPR trends shown earlier in Figures 3 and 2, respectively.

Furthermore, the empirical results on Sex are unsurprising given that women labour supplied to the market has larger elasticities than that of men, especially for married women (Cahuc et al., 2014, p. 56). Women labour force participation has been the subject of several studies to explain the difference between these elasticities, such as: (1) women's labour perceived to be more substitutable for unpaid household work; (2) the sensitivity of women's labour elasticities to her own (or her spouse's) wage rate, child-bearing and rearing children, as well as technological changes in household production (Bayudan-Dacuycuy, 2019; Borjas, 2013; Cahuc et al., 2014).

Coefficients and standard errors for Region, which serve as control for regional differences in LFP, are not included in Table 4. Overall, Region shows significant chisquare statistics.

\section{Decomposition Analysis and the Urban-Rural Difference in LFPR}

Aside from uncovering the determinants of LFP, this study attempts to determine to what extent do group characteristics, as against the behaviour of the groups associated with these characteristics, contribute to the difference in LFPR among these groups. This study's interest is in the difference in LFPR in the rural and urban areas. This is done using a regression-based decomposition technique first used in the labour economics literature originally developed by Oaxaca (1973) to analyse wage discrimination. It has since been used in the analysis of many other aspects of the labour market, and in many other settings where a decomposition of the effects on outcomes are warranted. (See Bowblis and Yun (2010) and Hirvonen (2016) for some examples, and Fortin, Lemieux and Firpo (2011) for a survey of the methodology.)

Understanding the difference in the LFPR in the rural and urban areas is necessary in order to support a country's formulation, implementation and monitoring of local government policies and programmes (ILO, 2018). Briones (2013) characterises employment conditions in the Philippine rural labour markets as casual or informal, with low skill requirements, low productivity and returns, and a greater concentration of poverty. Understanding the difference of these two areas' labour statistics can support the promotion of employment creation and human resource, and skills development appropriate to urban and rural areas; it can also serve as input in: (1) analysing poverty reduction, investment and employment promotion programmes; and (2) monitoring the progress towards specific goals (ILO, 2018). 
This paper explores two distinct groups, the rural and the urban populations indexed by $r$ and $u$ respectively, that possess different observable characteristics in the vector $x$. The variables in $x$ attempt to explain an outcome of interest $y$ to the researcher. For this study, which uses logit to explain LFP decision, the average outcome is the proportion of the group in the labour force, $\bar{y}_{r}$ and $\bar{y}_{u}$, which is simply the LFPR in the rural and urban areas respectively. The difference in the rural and urban LFPRs can therefore be expressed in the first equality below as:

$$
\begin{aligned}
\bar{y}_{r}-\bar{y}_{u} & =\overline{F\left(\boldsymbol{x}_{r} \boldsymbol{\beta}_{r}\right)}-\overline{F\left(\boldsymbol{x}_{u} \boldsymbol{\beta}_{u}\right)} \\
& =\left[\overline{F\left(\boldsymbol{x}_{r} \boldsymbol{\beta}_{r}\right)}-\overline{F\left(\boldsymbol{x}_{u} \boldsymbol{\beta}_{r}\right)}\right]+\left[\overline{F\left(\boldsymbol{x}_{u} \boldsymbol{\beta}_{r}\right)}-\overline{F\left(\boldsymbol{x}_{u} \boldsymbol{\beta}_{u}\right)}\right]
\end{aligned}
$$

In the second equality, the first term in square brackets shows the effects on the LFPR difference if both groups have the same response to $x$ as group $r$, the comparison group. The behaviour implied by the coefficient vector $\boldsymbol{\beta}_{r}$ is the same for both groups. It can also be interpreted as the expected change in the rural LFPR if it had urban population characteristics. Hence, the difference in LFPRs can be partly explained by the differences in characteristics between the groups.

The second term in square brackets is a counterfactual comparison, this time from the urban population's viewpoint. This term determines that part of the differences in LFPR had the urban group behaved differently - if they behaved more like the rural group. This is termed the coefficient effect and is the unexplained portion of the average outcome. These effects usually reflect behavioural differences among groups in cross-section data, while these show structural changes in time series analysis (see Contreras, et al., 2011 for a time series example.) Since Oaxaca's ordinary least squares (OLS) implementation, the method has been modified to overcome its limitations (Yun, 2004) and has been extended to non-linear models (Bauer \& Sinning, 2008; Fairlie, 2005). An exposition of the detailed decomposition that calculates the contribution of each factor in the characteristic and coefficient effects is done by Powers, Yoshioka and Yun (2011).

Table 5 shows the decomposition analysis of LFPR. The upper panel of Table 5 shows the results of the aggregate decomposition while the lower panel shows the individual contribution of the variables to LFP determination.

Nationwide LFPR in 2011 stands at $65.8 \%$ while rural and urban rates are at $67.4 \%$ and $64.0 \%$ respectively, indicating a difference of $3.4 \%$. As can be seen from Table 5 , the characteristic effects contribute only $5 \%$ to the urban-rural difference in LFPR while the coefficient effect, which is the unexplained portion of the overall difference, accounts for the remaining $95 \%$. This means that the disparity in LFPR can be reduced by only $5 \%$ even if the rural group becomes equivalent to the urban group in all the covariates in the model.

Also, as seen in Table 5, aside from a low overall contribution, individual characteristic effects are not statistically significant. Nonetheless this shows that the LFPR differential is reduced with more college graduates in the rural areas. The large overall coefficient effects on the other hand are dominated by the Sex, Age variables and the last three categories of Education levels which are all statistically significant. 
Table 5. Decomposition analysis of LFPR, urban vs. rural population, 2011

\begin{tabular}{|c|c|c|c|c|c|c|c|c|}
\hline Differences due to: & Coeff & SE & P-value & $\%$ & & & & \\
\hline Characteristics & 0.150 & 0.092 & 0.104 & 4.99 & & & & \\
\hline Coefficients & 2.860 & 0.259 & 0.000 & 95.01 & & & & \\
\hline Total & 3.010 & 0.241 & 0.000 & & & & & \\
\hline \multirow{2}{*}{$\begin{array}{l}\text { Individual } \\
\text { contributions: }\end{array}$} & \multicolumn{4}{|c|}{ Characteristics Effect } & \multicolumn{4}{|c|}{ Coefficient Effect } \\
\hline & Coeff & SE & P-value & $\%$ & Coeff & SE & P-value & $\%$ \\
\hline Sex & -2.032 & 5.158 & 0.694 & -67.49 & -3.305 & 0.163 & 0.000 & -109.79 \\
\hline Age & 0.015 & 0.039 & 0.693 & 0.51 & 5.043 & 0.572 & 0.000 & 167.53 \\
\hline \multicolumn{9}{|l|}{ Marital status } \\
\hline Single & -0.359 & 0.910 & 0.693 & -11.94 & -0.263 & 0.211 & 0.212 & -8.74 \\
\hline Married & -0.137 & 0.360 & 0.703 & -4.57 & 0.235 & 0.252 & 0.351 & 7.81 \\
\hline $\begin{array}{l}\text { Widowed } \\
\text { Divorced/Separated/ }\end{array}$ & -0.002 & 0.004 & 0.716 & 0.05 & 0.080 & 0.026 & 0.002 & 2.67 \\
\hline Annulled & 0.158 & 0.398 & 0.691 & 5.26 & -0.047 & 0.025 & 0.053 & -1.57 \\
\hline \multicolumn{9}{|l|}{ Educational level } \\
\hline No grade completed & 0.417 & 1.048 & 0.691 & 13.86 & 0.035 & 0.008 & 0.000 & 1.16 \\
\hline Elementary undergraduate & -1.424 & 3.681 & 0.699 & -47.32 & 0.058 & 0.034 & 0.088 & 1.92 \\
\hline Elementary graduate & -0.455 & 1.190 & 0.702 & -15.12 & 0.030 & 0.043 & 0.488 & 0.99 \\
\hline High school undergraduate & 1.048 & 2.655 & 0.693 & 34.82 & 0.034 & 0.063 & 0.591 & 1.13 \\
\hline High school graduate & 0.348 & 0.879 & 0.692 & 11.58 & -0.476 & 0.106 & 0.000 & -15.82 \\
\hline College undergraduate & -2.013 & 5.151 & 0.696 & -66.88 & -0.561 & 0.087 & 0.000 & -18.65 \\
\hline College graduate & 4.585 & 11.523 & 0.691 & 152.33 & -0.409 & 0.104 & 0.000 & -13.57 \\
\hline Constant & & & & & 2.406 & 0.850 & 0.005 & 79.93 \\
\hline
\end{tabular}

\section{Conclusion}

This study shows that an individual's decision to participate in the labour force is influenced by location, sex, age, marital status and educational level. The rural man, single individual, who is older, and possesses a higher educational level is more likely to participate in the labour force. A decomposition of LFPR difference between rural and urban areas shows that this is driven more by differences in behaviour as shown by the coefficient effect rather than by population characteristics.

The importance of education to LFP is once again re-emphasised in this study. It shows that each step up in the educational attainment ladder is associated with particular large jumps in LFP - 21.5 percentage points with the completion of a college degree, 10.4 percentage points with a high school degree, and 11.5 percentage points with an elementary degree. This greater LFP may be due to the more educated individuals increased propensity to seek employment, or to the greater opportunity 
cost of staying out of the labour market. Either way, educational attainment and LFP is important in understanding the returns of education (Bowen \& Finegan, 1966).

Consequently, the education and LFP link should inform government policies. Public policies focused on increasing participation at all educational levels, on completing educational levels, on minimising drop-out rates, on offering alternative/flexible vocational and employment-based education or schooling models, are some policies to consider, some of which are already being done. Furthermore, the education and LFP link provides another measure of government programme effectiveness in both education (e.g., K-12, free college education in state universities), and social welfare (e.g., conditional cash transfers tied to school attendance).

The woman's lower likelihood of participation in the labour market is once again highlighted in this study. Increasing LFP can be a key aspect of the Philippines economic growth strategy, similar to that of Europe (Balleer, Gomez-Salvador \& Turunen, 2014). Public policies focused on incentivizing companies to offer more flexible working-time arrangements or on-site childcare support, on less taxation of second earners (relative to single earners), on more generous paid parental leave, are some policies to consider to encourage increases in women LFP (ILO, 2017).

This can be considered a baseline study given the absence of such previous studies in the Philippines. As a baseline study, this study can be extended in three ways. One is to take a dynamic approach to the study of LFP versus the stock perspective taken by this study. Still using LFS data, one can either adopt a set of retrospective questions, or exploit the sample design of the survey which allows for the construction of panels of short duration (Artola \& Bell, 2001). Two is to explore the root causes and implications of LFPR trends in different categories of the population (e.g., men, women, youth). Three is to explore the causes of the dips in LFP between elementary graduate to high school undergraduate and between high school graduate to college undergraduate, as well as the decrease in the likelihood of participation in the labour force by college undergraduates.

\section{References}

Aaronson, D., Hu, L., Seifoddini, A., \& Sullivan, D.G. (2014). Declining labour force participation and its implications for unemployment and employment growth. Economic Perspectives, 38(4), 100-138.

Artola, C., \& Bell, U.L. (2001). Identifying labour market dynamics using labour force survey data (ZEW Discussion Paper No. 01-44). Mannheim, Germany: Centre for European Economic Research. Retrieved from http://ftp.zew.de/pub/zew-docs/dp/dp0144.pdf

Balleer, A., Gomez-Salvador, R., \& Turunen, J. (2014). Labour force participation across Europe: A cohort-based analysis. Empirical Economics, 46(4), 1385-1415. https://doi.org/10.1007/ s00181-013-0716-3

Bauer, T.K., \& Sinning, M. (2008). An extension of the Blinder-Oaxaca decomposition to nonlinear models. AStA Advances in Statistical Analysis, 92(2), 197-206. https://doi.org/10.1007/ s10182-008-0056-3

Bayudan-Dacuycuy, C. (2019). Examining the women's low labour market participation rate in the Philippines: Is housework the missing link? (PIDs Discussion Paper Series, No. 201905). Quezon City, Philippines: Philippine Institute for Development Studies. Retrieved from https://pidswebs.pids.gov.ph/CDN/PUBLICATIONS/pidsdps1905.pdf 
Borjas, G.J. (2013). Labour economics (6th ed.). Boston, MA: McGraw-Hill/Irwin.

Bowblis, J.R., \& Yun, M.S. (2010). Racial and ethnic disparities in the use of drug therapy. Social Science Research, 39(4), 674-684. https://doi.org/10.1016/j.ssresearch.2010.03.010

Bowen, W.G., \& Finegan, T.A. (1966). Educational attainment and labour force participation. The American Economic Review, 56(1/2), 567-582. Retrieved from: https://www.jstor.org/stable/ i331576

Bowen, W.G., \& Finegan, T.A. (1969). The economics of labour force participation. Princeton, N.J.: Princeton University Press.

Briones, R. (2013). Agriculture, rural employment, and inclusive growth (PIDS Discussion Paper Series, No. 2013-39). Quezon City, Philippines: Philippine Institute for Development Studies. Retrieved from https://serp-p.pids.gov.ph/serp-p//details. php?pid=5215\&param=+Briones+Roehlano+M

Brooks, R. (2002). Why is unemployment high in the Philippines? (IMF Working Paper 2002/23). Washington DC: International Monetary Fund. https://doi.org/10.5089/9781451844054.001

Cahuc, P., Carcillo, S., \& Zylberberg, A. (2014). Labour economics (2nd ed.). Cambridge, MA: MIT Press.

Clark, R.L., \& Anker, R. (1993). Cross-national analysis of labor force participation of older men and women. Economic Development and Cultural Change, 41(3), 489-512. https://doi. org/10.1086/452029

Contreras, D., De Mello, L., \& Puentes, E. (2011) The determinants of labour force participation and employment in Chile. Applied Economics, 43(21), 2765-2776. https://doi.org/10.1080/ 00036840903373303

Cullison, W.E. (1979). The determinants of labour force participation: An empirical analysis (FRBR Working Paper 79-3). Richmond, VA: Federal Reserve Bank of Richmond. Retrieved from https://www.richmondfed.org/publications/research/working_papers/1979/wp_79-3

Daly, M.C., \& Regev, T. (2007). Labour force participation and the prospects for U.S. growth (FRBSF Economic Letters No. 2007-33). San Francisco, CA: Federal Reserve Bank of San Francisco. Retrieved from https://www.frbsf.org/economic-research/publications/economicletter/2007/november/labor-force-participation-us-growth/

Ehrenberg, R.G., \& Smith, R.S. (2018). Modern labour economics: Theory and public policy (13th ed.). New York, NY: Routledge. https://doi.org/10.4324/9781315101798

Encarnacion Jr, J. (1974). Fertility and labour force participation: Philippines 1968. The Philippine Review of Business and Economics, 11(2), 113-144.

Fairlie, R.W. (2005). An extension of the Blinder-Oaxaca decomposition technique to logit and probit models. Journal of Economic and Social Measurement, 30(4), 305-316. https://doi.org/ 10.3233/JEM-2005-0259

Fernández, R., Fogli, A., \& Olivetti, C. (2004). Mothers and sons: Preference formation and female labour force dynamics. The Quarterly Journal of Economics, 119(4), 1249-1299. https://doi. org/10.1162/0033553042476224

Fleisher, B.M. (1971). The economics of labour force participation: A review article. The Journal of Human Resources, 6(2), 139-148.

Fortin, N., Lemieux, T., \& Firpo, S. (2011). Decomposition methods in economics. In O. Ashenfelter \& D. Card (Eds.), Handbook of Labour Economics Volume 4A (pp. 1-102). Amsterdam: Elsevier. https://doi.org/10.1016/S0169-7218(11)00407-2

Grigoli, F., Koczan, Z., \& Topalova, P. (2018). Drivers of labour force participation in advanced economies: Macro and micro evidence (IMF Working Paper No. 18/150). Washington DC: International Monetary Fund. Retrieved from https://www.imf.org/en/Publications/WP/ Issues/2018/06/25/Drivers-of-Labor-Force-Participation-in-Advanced-Economies-Macro-andMicro-Evidence-45977 
Hirvonen, K. (2016). Rural-urban differences in children's dietary diversity in Ethiopia: A Poisson decomposition analysis. Economics Letters, 147(October), 12-15. https://doi.org/10.1016/j. econlet.2016.08.003

International Labour Organization. (2017). ILO labour force estimates and projections: 1990-2030. Geneva, Switzerland: Author. Retrieved from https://www.ilo.org/ilostat-files/Documents/ LFEP.pdf

International Labour Organization. (2018). Rural-urban labour statistics. Geneva, Switzerland: Author. Retrieved from https://www.ilo.org/wcmsp5/groups/public/---dgreports/---stat/ documents/meetingdocument/wcms_636038.pdf

International Labour Organization. (2019, November). Labour force participation rate by rural/ urban areas - ILO modelled estimates. Geneva, Switzerland: Author. Retrieved from https:// www.ilo.org/shinyapps/bulkexplorer53/

International Labour Organization. (n.d.). Labour force participation rate. Geneva, Switzerland: Author. Retrieved from https://www.ilo.org/ilostat-files/Documents/description_LFPR_EN.pdf

Jaumotte, F. (2003). Female labour force participation: Past trends and main determinants in OECD countries (Economics Department Working Papers No. 376). Paris, France: Organisation for Economic Co-operation. https://doi.org/10.1787/082872464507

Juhn, C., \& Potter, S. (2006). Changes in labour force participation in the United States. Journal of Economic Perspectives, 20(3), 27-46. https://doi.org/10.1257/jep.20.3.27

Montalvo, J.G. (2006). Regional evolutions in labour markets in the Philippines: A dynamic approach. Journal of Asian Economics, 17(3), 448-477. https://doi.org/10.1016/j.asieco.2006. 04.009

Oaxaca, R. (1973). Male-female wage differentials in urban labor markets. International Economic Review, 14(3), 693-709. https://doi.org/10.2307/2525981

Orbeta, A.C. (2005). Children and the labour force participation and earnings of parents in the Philippines (ADB Institute Discussion Paper No. 30). Tokyo, Japan: Asian Development Bank Institute. Retrieved from https://www.adb.org/publications/children-and-labor-forceparticipation-and-earnings-parents-philippines

Philippine Statistics Authority (PSA). (2011, January). Labour Force Survey. Quezon City, Philippines: Author.

Philippine Statistics Authority (PSA). (2016, January). Labour Force Survey. Quezon City, Philippines: Author.

Powers, D.A., Yoshioka, H., \& Yun, M.S. (2011). Mvdcmp: Multivariate decomposition for nonlinear response models. The Stata Journal, 11(4), 556-576. https://doi.org/10.1177/ $1536867 X 1201100404$

Rodriguez, E.R., \& Tiongson, E.R. (2001). Temporary migration overseas and household labour supply: Evidence from urban Philippines. International Migration Review, 35(3), 709-725. https://doi.org/10.1111/j.1747-7379.2001.tb00037.x

Scott, L.C., Smith, L.H., \& Rungeling, B. (1977). Labour force participation in southern rural labour markets. American Journal of Agricultural Economics, 59(2), 266-274.

Tiefenthaler, J. (1994). A multisector model of female labour force participation: Empirical evidence from Cebu Island, Philippines. Economic Development and Cultural Change, 42(4), 719-742. https://doi.org/10.1086/452117

Tüzemen, D. (2018). Why are prime-age men vanishing from the labour force? Economic Review, Federal Reserve Bank of Kansas City, 103(1), 5-30. https://doi.org/10.18651/ER/1q18Tuzemen

World Bank. (2019). Labour force participation rate. Washington, DC: Author. Retrieved from https://data.worldbank.org/indicator/

World Bank. (2020). Labour force participation rate for ages 15-24, total (\%) (national estimate) - Philippines. Washington, DC: Author. Retrieved from https://data.worldbank.org/indicator/ SL.TLF.ACTI.1524.NE.ZS?locations=PH 
World Bank. (2020). Labour force participation rate, female (\% of female population ages 15+) (national estimate) - Philippines. Washington, DC: Author. Retrieved from https://data. worldbank.org/indicator/SL.TLF.CACT.FE.NE.ZS?locations=PH\&view=chart

World Bank. (2020). Labour force participation rate, male (\% of male population ages 15+) (national estimate) - Philippines. Washington, DC: Author. Retrieved from https://data. worldbank.org/indicator/SL.TLF.CACT.NE.ZS?locations=PH\&view=chart

World Bank. (2020). Labour force participation rate, total (\% of total population ages 15+) (national estimate) - Philippines. Washington, DC: Author. Retrieved from https://data. worldbank.org/indicator/SL.TLF.CACT.NE.ZS?locations=PH\&view=chart

World Bank. (2020). Labour force, total - Philippines. Washington, DC: Author. Retrieved from https://data.worldbank.org/indicator/SL.TLF.TOTL.IN?locations=PH

Yun, M.S. (2004). Decomposing differences in the first moment. Economics Letters, 82(2), 275280. https://doi.org/10.1016/j.econlet.2003.09.008 
